\title{
Socio-Economic Profile of Vegetable Growers under Horticulture based Module of Farmer FIRST Project in Balaghat (M.P.), India
}

\author{
Mohammad Imran Khan ${ }^{1}$, Sharad Bisen ${ }^{1}$ and Gaurav Mahajan ${ }^{2} *$ \\ ${ }^{1}$ Raja Bhoj College of Agriculture, Balghat Murjhad Farm, Warseon, Jawaharlal Nehru \\ Krishi Vishwa Vidalaya, Madhya Pardesh, India \\ ${ }^{2}$ All India Coordinated Research Project on Maize, Z.A.R.S. Chhindwara, Jawaharlal Nehru \\ Krishi Vishwa Vidalaya, Madhya Pardesh, India \\ *Corresponding author
}

\begin{tabular}{l} 
K e y w o r d s \\
Socio-economic, \\
Vegetable, \\
First Project \\
Article Info \\
Accepted: \\
$\begin{array}{l}\text { 28 February } 2019 \\
\text { Available Online: } \\
\text { 10 March } 2020\end{array}$ \\
\hline
\end{tabular}

A B S T R A C T

The present study attempts to scrutinize the socio-economic profile of vegetable farmers of Balaghat Murjhad farm, Waraseoni Madhya Pradesh. The study was conducted in three villages located at Koppe, Chillod, and lendejhari, Balaghat Murjhad farm, Waraseoni. Data for the study was collected from a sample of 120 vegetable farmers. The findings of the study reveal that, the $53.337 \%$ of the vegetable farmers had high school education. Among the sample about 52.50 per cent of farmers were small. As far as social participation is concerned about 20 per cent of vegetable farmers were the member of two organizations. The study revealed that the farmer can get an additional income of about Rs. 283 per day in addition to their routine work from their badi with the production of different vegetables. The socio-economic status of the farmers can be improved by imparting technical knowledge/ training to vegetable farmers, increasing their education level and increasing their social participation.

\section{Introduction}

Among the low income households vegetable cultivation has an increasingly important commercial role to play. It has great potentiality and scope for improving socioeconomic condition of small and marginal farmers as vegetable growing in comparison to food grains cultivation provides higher yield and high economic return in short time. Vegetable growing being an intensive programme, it has more income per unit area and employment generation in short span of time. In India where per capita availability of land has been gradually decreasing and as such the small holdings are becoming smaller 
day by day and the deprived farmers are in a fix to adopt modern agricultural practices. The exorbitant increase in the price of agricultural inputs is making traditional agriculture less remunerative. Whatever they are producing that is hardly sufficient to meet the food requirement of the family, fodder and feed needs of domestic animals. As the small and marginal farmers have no surplus produce for the sale, the increasing price of inputs is responsible for making agriculture unattractive with the result rural youths are migrating from rural areas to urban area in search of jobs to ensure better livelihoods.

To address the problem of small, marginal or landless farmers, GOI started the Farmer FIRST project (Farmers Farm, Innovations, Resources, Science \& Technology). The programme aims at enhancing farmer's scientist interface for technology development and application. It was, therefore, required to study the profile of vegetable growers to get some knowledge about socio economic profile of vegetable growers.

\section{Materials and Methods}

Present study was conducted in the adopted villages of Farmer FIRST project i.e. Koppe, Chillod, and lendejhari purposely run under Raja Bhoj College of Agriculture, Balaghat Murjhad farm, Waraseoni, JNKVV Jabalpur, M.P. A total of 120 farmers were under study during the two consecutive year 2018-2019. For precise sampling and study twenty (20) farmers from each village and a total of sixty (60) farmers were selected under production of vegetables in the Badi (area surrounding the house) during rabi season.

They were provided with plug trays, vermi compost, improved seeds of vegetables, for an area of about $2000 \mathrm{~m}^{2}$ ( $1 / 2$ acre) under Farmer FRIST project. The farmers have the irrigation facilities. Pre testing interview schedule was prepared for primary data collection, whereas the secondary data were collected from base line survey of the project, Gram Panchayat, Sarpanch, Sachive and progressive farmers through direct face to face interviews. Frequency, percentage distribution and mean yield and income were used as statistical tools for the study.

\section{Results and Discussion}

The socioeconomic approach is mainly concerned with the social, economic, and political aspects of individuals or social groups in society. Generally the socioeconomic approach focuses on identifying the adaptive capacity of individuals or communities based on their internal characteristics such as age, education, size of land holding, social participation, farm power and so on. Variations of these factors are responsible for the variations in socioeconomic characteristics of farmers. The findings about the socioeconomic status of the study area are given in Table 1.

\section{Age}

Study indicates that majority of the vegetable farmers $(47.50 \%)$ were in middle age group, 20.83 per cent of vegetable farmers belonged to old age group and 31.67 per cent vegetable farmers were in young age group. Singh et. al., (2006) have also reported the similar findings.

\section{Education}

With regards to education a higher percentage of $(53.33 \%)$ of respondents possessed high school and above level of formal education followed by middle school level (26.67 \%), illiterate $(2.50 \%)$ and primary level $(17.80 \%)$ of education. The works of Adebayo and Oladele (2013) were in line with the present finding. 


\section{Land Holding}

Study depicts that 38.33 per cent of vegetable farmers were having less than 1 ha of land, thus belonged to marginal farmers category. The farmers who belonged to small and medium categories were 52.30 per cent and 9.17 per cent, respectively. Data also shows that none of vegetable farmers were having large land holding.

Thus, it may be concluded that majority of the vegetable farmers were small farmers having 1.01 to 1 hectare of agricultural land. This is due to the fact that in Madhya Pradesh, per capita agricultural land is comparatively less. The other reason may be the fragmentation of the holdings due to nuclear family system Mahajan (2016) was of same opinion.

\section{Social Participation}

The table 1 shows that the 45.83 per cent of the vegetable farmers were the member of one organization, while $34.17 \%$ were the member of 7-10 organizations. In this way, $80 \%$ of vegetable farmers were associated with the organizations like panchayats, cooperatives, youth-club, religious and political organization. It can also be concluded that only $4.39 \%$ of vegetable farmers were holding office in one or more organization. Yadav (2009) reported that most of beneficiaries $(58 \%)$ were not the members of any organization. It may due to fact that they may not be aware about the organizations or its benefits

\section{Farm Power}

Farm Power shows the number of instruments the farmer has to deploy for its agricultural needs and allied farming. For measuring the variable, open response from farmers was recorded. Table 1 depicts that majority of vegetable farmers $(52.50 \%)$ had have low level of farm power followed by medium level $(26.67 \%)$. Findings are in the line with the results of Pawal (2014).

With regards to Psychological attributes of the respondent's economic motivation, scientific orientation and innovation proneness among the respondents were studied. With regards to economic motivation a higher percentage of $(40.83 \%)$ economic motivation was carried out by medium group of respondents followed by high group (35 $\%)$. scientific orientation was high among medium group of respondents i.e. $40.83 \%$ followed by high group of respondents (34.17 $\%$ ) whereas most of the vegetable growers $(45.83 \%)$ had high level of innovation proneness. (Table -1$)$

In the study of communicational attributers of the respondent's due to time to time contact and providing need based trainings to the farmers by Farmer FIRST project experts and extension personals, higher percentage of vegetable growers $(42.50 \%)$ had high mass media exposure and contact with the development agencies. (Table -1$)$

The findings about the income generation of the farmers through vegetable production of the study area are given in Table 2 , reveals that the distribution of production potential of rabi vegetables at farmer's field under badi that okra, brinjal, tomato, cabbage all were cultivated in $400 \mathrm{~m}^{2}$ followed by chilli in 300 $\mathrm{m}^{2}$ and bottle guard in $100 \mathrm{~m}^{2}$ all vegetables were grown in total $2000 \mathrm{~m}^{2}$ area of badi. The production potential of vegetable in terms of average production showed that brinjal, followed by tomato was more remunerative in terms of production. Similar findings were reported by Bose et.al.,(2015). 
Table.1 Distribution of the vegetable growers according to their socio - personal, Psychological and communicational attributes (Mean of two years)

\begin{tabular}{|c|c|c|c|}
\hline \multirow{2}{*}{$\begin{array}{l}\text { S. } \\
\text { No. }\end{array}$} & \multirow[t]{2}{*}{ Categories of attributes } & \multicolumn{2}{|c|}{ Categories of respondents } \\
\hline & & $\mathrm{N}=120$ & $\%$ \\
\hline $\mathbf{A}$ & \multicolumn{3}{|c|}{ Socio personal attributes of the respondents } \\
\hline \multirow[t]{2}{*}{1.} & Age & & \\
\hline & $\begin{array}{l}\text { Young }(18-35 \text { years }) \\
\text { Middle }(36-55 \text { years }) \\
\text { Old (above } 55 \text { years })\end{array}$ & $\begin{array}{l}38 \\
57 \\
25\end{array}$ & $\begin{array}{l}31.67 \\
47.50 \\
20.83\end{array}$ \\
\hline \multirow[t]{2}{*}{2.} & Education & & \\
\hline & $\begin{array}{l}\text { Illiterate } \\
\text { Primary passed } \\
\text { Middle passed } \\
\text { High school passed and above }\end{array}$ & $\begin{array}{c}3 \\
21 \\
32 \\
64\end{array}$ & $\begin{array}{l}2.50 \\
17.50 \\
26.67 \\
53.33\end{array}$ \\
\hline \multirow[t]{2}{*}{3} & Size of land holdings & & \\
\hline & $\begin{array}{l}\text { Marginal (Up to } 1 \mathrm{ha}) \\
\text { Small (1.01 to } 2 \text { ha) } \\
\text { Medium ( } 2.01 \text { to } 5 \text { ha) } \\
\text { Large (Above } 5 \text { ha) }\end{array}$ & $\begin{array}{c}46 \\
63 \\
11 \\
0\end{array}$ & $\begin{array}{c}38.33 \\
52.50 \\
9.17 \\
0.0\end{array}$ \\
\hline \multirow[t]{2}{*}{4.} & Social participation & & \\
\hline & $\begin{array}{l}\text { Low }(3-6) \\
\text { Medium }(7-10) \\
\text { High }(11-14)\end{array}$ & $\begin{array}{l}24 \\
41 \\
55\end{array}$ & $\begin{array}{l}20.00 \\
34.17 \\
45.83\end{array}$ \\
\hline \multirow[t]{2}{*}{5.} & Farm power & & \\
\hline & $\begin{array}{l}\text { Low (Up to 5) } \\
\text { Medium }(13-16) \\
\text { High (above } 16)\end{array}$ & $\begin{array}{l}63 \\
32 \\
25\end{array}$ & $\begin{array}{l}52.50 \\
26.67 \\
20.83\end{array}$ \\
\hline \multirow[t]{2}{*}{6.} & Material possession & & \\
\hline & $\begin{array}{l}\text { Low (Up to } 12) \\
\text { Medium }(13-16) \\
\text { High (above } 16)\end{array}$ & $\begin{array}{l}46 \\
43 \\
31\end{array}$ & $\begin{array}{l}38.33 \\
35.83 \\
25.83\end{array}$ \\
\hline B. & \multicolumn{3}{|c|}{ Psychological attributes of the respondents } \\
\hline \multirow[t]{2}{*}{1.} & Economic Motivation & & \\
\hline & $\begin{array}{l}\text { Low }(24-30) \\
\text { Medium }(31-36) \\
\text { High }(37-42)\end{array}$ & $\begin{array}{l}29 \\
49 \\
42\end{array}$ & $\begin{array}{l}24.17 \\
40.83 \\
35.00\end{array}$ \\
\hline \multirow[t]{2}{*}{2.} & Scientific orientation & & \\
\hline & $\begin{array}{l}\text { Low }(24-30) \\
\text { Medium }(31-36) \\
\text { High }(37-42)\end{array}$ & $\begin{array}{l}30 \\
49 \\
41\end{array}$ & $\begin{array}{l}25.00 \\
40.83 \\
34.17\end{array}$ \\
\hline 3. & Innovation proneness & & \\
\hline
\end{tabular}




\begin{tabular}{|c|l|c|c|}
\hline & Low (Up to 5) & 22 & 18.33 \\
& Medium (6-9) & 43 & 35.83 \\
& High (above 9) & 55 & 45.83 \\
\hline C. & Communicational attributes of the respondents & \\
\hline 1. & Mass media exposure & \\
\hline & Low (up to 7) & 25 & 20.83 \\
& Medium (8 - 11) & 44 & 36.67 \\
& High (above 11) & 51 & 42.50 \\
\hline $\mathbf{2 .}$ & Contact with development agencies & & \\
\hline & Low (Up to 6) & 25 & 20.83 \\
& Medium (7 - 10) & 44 & 36.67 \\
& High (above 10) & 51 & 42.50 \\
\hline
\end{tabular}

Table.2 Distribution of Production potential of rabi vegetables at farmer's field under badi (Mean of two years)

\begin{tabular}{|l|l|c|c|c|}
\hline S. No. & Name of crop & Area $^{\mathbf{2}}$ & $\begin{array}{c}\text { Average production in } \\
\text { kg }\end{array}$ & Duration Days \\
\hline $\mathbf{1}$ & Okara & 400 & 369 & 87 \\
\hline $\mathbf{2}$ & Bottle Guard & 100 & 162 & 88 \\
\hline $\mathbf{3}$ & Chilli & 300 & 152 & 140 \\
\hline $\mathbf{4}$ & Brinjal & 400 & 1675 & 125 \\
\hline $\mathbf{5}$ & Tomato & 400 & 1370 & 125 \\
\hline $\mathbf{6}$ & Cabbage & 400 & 1317 & 115 \\
\hline
\end{tabular}

Table.3 Distribution of Income generation (Rs.) with the production of vegetables from $1 / 2$ acre area $\left(2000 \mathrm{~m}^{2}\right)$ of badi (Mean of two years)

\begin{tabular}{|l|l|c|c|c|c|c|}
\hline $\begin{array}{l}\text { S. } \\
\text { No. }\end{array}$ & Name of crop & $\begin{array}{c}\text { Area } \\
\mathbf{m}^{\mathbf{2}}\end{array}$ & $\begin{array}{c}\text { Cost of } \\
\text { cultivation } \\
\text { (Rs.) }\end{array}$ & $\begin{array}{c}\text { Gross } \\
\text { return (Rs.) }\end{array}$ & $\begin{array}{c}\text { Net } \\
\text { return } \\
\text { (Rs.) }\end{array}$ & $\begin{array}{c}\text { Net } \\
\text { Income / } \\
\text { Day }\end{array}$ \\
\hline $\mathbf{1}$ & Okara & 400 & 2775 & 7569 & 4794 & 55 \\
\hline $\mathbf{2}$ & Bottle Guard & 100 & 625 & 1784 & 1159 & 13 \\
\hline $\mathbf{3}$ & Chilli & 300 & 1100 & 2434 & 1334 & 10 \\
\hline $\mathbf{4}$ & Brinjal & 400 & 2100 & 13435 & 11335 & 91 \\
\hline $\mathbf{5}$ & Tomato & 400 & 2665 & 13030 & 10365 & 83 \\
\hline $\mathbf{6}$ & Cabbage & 400 & 2380 & 5944 & 3564 & 31 \\
\hline & Total & $\mathbf{2 0 0 0}$ & $\mathbf{1 1 6 4 5}$ & $\mathbf{4 4 1 9 6}$ & $\mathbf{3 2 5 5 1}$ & $\mathbf{2 8 3}$ \\
\hline
\end{tabular}

The economic analysis of the inputs and out puts of the vegetables growers showed that on the basis of average production and cost involved in the production for the six different vegetables (Table-3) shows that a family having an area of $(1 / 2$ acre $) 2000 \mathrm{~m}^{2}$ can earn net return of Rs. 4794 from okra, Rs. 1159 from bottle guard, Rs. 1334 from chilli, Rs. 11335 from brinjal, Rs. 10365 from tomato and Rs. 3564 from cabbage. Further it shows 
that the farmer can get an additional income of about Rs. 283 per day in addition to their routine work from their badi with the production of different vegetables. These finding are in collaboration with those of Mahajan, (2017).

The socioeconomic characteristics of farmers are important for better policy options. On the basis of the findings it is suggested that socioeconomic status of the farmers can be improved by imparting technical knowledge/ training to vegetable farmers, increasing their education level and increasing their social participation.

\section{Acknowledgement}

The author acknowledge the financial help provided by Government of India and Dr Gaurav Mahajan who helped in data analysis and compiling of the manuscript

\section{References}

Adebayo, S. A. and Oladele, O. I. Socioeconomic status of organic vegetable farmers in South West Nigeria. Journal of Food, Agriculture \& Environment. 11(2):397-402. 2013

Bose, U.S., Mahajan, G and Kumar.A., Yield and economics of cauliflower as affected by organic, inorganic and biofertilizers. Progressive Research. 10 (Special-VII) : 3946-3948. 2015.

Mahajan, G. Analysis of cost and returns of kodo millet production under rainfed condition of Kymore plateau and Satpura hill region. Bioved, 28(2) : 315-320. 2017.

Mahajan, G. Effect of kodo millet (Paspalum scrobiculatum) based intercropping system on yield and economics of kodo millet under rainfed conditions, New Agriculturist, 27(1) : 121-124, 2016

Pawal, R. D. Pisure, B. L. Jamadar, C. R. Relationship between socio-economic characteristics of brinjal growers with their adoption gap in production practices. Trends in Biosciences. 7(19):2903-2906. 2014

Singh, D., Prakash, S. and Saroj, P.L. Impact of perceived characteristic and adoption level of trained trainees in KVK about plant protection measures. Annals Plant Protection Sciences; 14 (1): 215217.2006.

Yadav, A. Constraints Analysis of National Rural Employment Guarantee Scheme in Fatehpur district (U.P.). Unpu. M.S.c.(Ag.). Thesis, Deptt. of Argil. Extension, CSAUA\&T, Nawabganj, Kanpur. U.P. 2009.

\section{How to cite this article:}

Mohammad Imran Khan, Sharad Bisen and Gaurav Mahajan. 2020. Socio-Economic Profile of Vegetable Growers under Horticulture based Module of Farmer FIRST Project in Balaghat (M.P.), India. Int.J.Curr.Microbiol.App.Sci. 9(03): 3252-3257.

doi: https://doi.org/10.20546/ijcmas.2020.903.372 